\title{
Are blood pressure surges associated with sympathetic stimulation aggravated by $\beta$-adrenoceptor antagonist treatment?
}

\section{Cyrus R. Kumana \\ Patterns of sympathetically mediated acute pressor responses}

Department of Medicine, University of Hong Kong, Queen Mary Hospital, Pok Fu Lam Road, Hong Kong.
The classical work of Goldenberg et al. (1948) and Barcroft \& Starr (1952) in healthy volunteers, demonstrated that intravenous (i.v.) infusion of adrenaline (over 5-35 minutes) reduced diastolic blood pressure and peripheral resistance $\left(\alpha_{1}\right.$-receptor mediated vasoconstriction being more than balanced out by $\boldsymbol{\beta}_{2^{-}}$ receptor mediated vasodilatation), but increased systolic pressure and heart rate $(\beta$-receptor mediated and reflex effects). By contrast, noradrenaline infusion increased peripheral resistance, diastolic and systolic pressure ( $\alpha$-receptor mediated vasoconstriction) and reduced heart rate (reflexly). During prolonged (1 hour) catecholamine infusions, however, feedback through presynaptic $\beta$ (facilitatory) and $\alpha_{2}$ (inhibitory) receptors may become evident (Brown et al., 1985) and greatly complicate the resultant haemodynamic response.

Theoretical concerns, that antagonism of $\beta$-receptor mediated vasodilatation might elevate blood pressure in sustained hypertension, were eventually refuted. However, Prichard \& Ross (1966) demonstrated, in phaeochromocytoma patients pretreated with phenoxybenzamine, increases in lying and standing systolic and diastolic blood pressure lasting about 8 hours after single $80 \mathrm{mg}$ doses of oral propranolol. Presumably, $\beta$-receptor mediated vasodilatation due to circulating adrenaline was antagonized, thus unmasking $\alpha$-receptor mediated vasoconstriction leading to increased peripheral resistance and venoconstriction. Objective haemodynamic measurements in healthy volunteers (Van Herwaarden et al., 1977) and hypertensive patients (Johnsson, 1975) infused i.v. adrenaline were entirely consistent with this explanation, in

Correspondence: C.R. Kumana, B.Sc., M.B., F.R.C.P. (London \& Canada)

Accepted: 6 March 1986 that the pattern of responses was identical; the decreases in diastolic pressure and peripheral resistance giving way to increases after treatment with propranolol. However, after treatment with metoprolol (a selective antagonist less liable to block $\beta$-receptor mediated vasodilatation), the pattern of responses to adrenaline infusion was unchanged.

Other stimuli likely to involve sympathetic activation, such as isometric hand grip, brief periods of incremental and steady state exercise and cold exposure, entail increases in diastolic and systolic pressure except that with dynamic exercise only systolic pressure increased. The pattern of pressor responses was no different in the presence of selective or nonselective $\beta$-blockade (Van Herwaarden et al., 1979; Morrison et al., 1982). Thus, the latter were consistent with predominantly neurogenic (noradrenaline mediated) stimulation and widespread vasoconstriction. As vascular $\boldsymbol{\beta}$-receptors (mainly $\boldsymbol{\beta}_{2}$ ) as opposed to $\alpha$ receptors (mainly $\alpha_{1}$ ), may not be innervated (Man in't'Veld et al., 1983), the minimal $\beta$-receptor agonism from neurally released noradrenaline was unlikely to evoke clinically significant vasodilatation and the presence of selective versus nonselective $\beta$-blockade was probably irrelevant to the ensuing pressor responses.

It is thus possible to recognize two distinct patterns of sympathetically mediated acute pressor responses which appear to entail different pathophysiological processes and humoral transmitters and are evoked by different sets of stimuli (see Table I). This classification must be regarded as tentative and over simplified, since the predominant pattern of haemodynamic response is often unclear. Sometimes both noradrenergic (neural) and adrenergic (humoral) processes seem to be involved with the pressor response (at different times or simultaneously, or under different circumstances), and occasionally neither may contribute significantly. Respective responses were assigned on physiological and pharmacological character- 
Table I Pressor stimuli presumed to be sympathetically mediated

\begin{tabular}{|c|c|}
\hline $\begin{array}{l}\text { Predominantly due to } \\
\text { noradrenaline (neural } \\
\text { release) or like } \\
\text { substance }\end{array}$ & $\begin{array}{l}\text { Predominantly due to } \\
\text { circulating } \\
\text { adrenaline or } \\
\text { like substance }\end{array}$ \\
\hline $\begin{array}{l}\text { Physiological stresses } \\
\text { - Cold exposure } \\
\text { - Isometric exercise } \\
\text { - Dynamic exercise } \\
\text { - Acute mental stress? } \\
\text { - Sexual intercourse? }\end{array}$ & $\begin{array}{l}\text { Pathological processes } \\
\text { - Phaeochromocytoma? } \\
\text { - Hypoglycaemic attacks } \\
\text { (brittle diabetes) } \\
\text { - Schizophrenia? }\end{array}$ \\
\hline $\begin{array}{l}\text { Pharmacolog } \\
\text { - Smoking cigarettes? } \\
\text { - Phenylephrine used as } \\
\text { topical decongestant } \\
\text { - Alcohol? }\end{array}$ & $\begin{array}{l}\text { l interventions } \\
\text { - Infiltrative local } \\
\text { anaesthesia together } \\
\text { with adrenaline } \\
\text { - Clonidine therapy/ } \\
\text { withdrawal? }\end{array}$ \\
\hline $\begin{array}{l}\text { Systolic \& diastolic BP in- } \\
\text { crease } \\
\text { HR usually } \downarrow \text { (reflexly) }\end{array}$ & $\begin{array}{l}\text { Increase in systolic but de- } \\
\text { crease in diastolic BP } \\
\text { HR usually } \uparrow \text { (directly \& } \\
\text { reflexly) }\end{array}$ \\
\hline $\begin{array}{l}\text { BP surge unaffected by } \beta \text { - } \\
\text { blockade (nonselective or } \\
\text { selective) } \\
\alpha_{1} \text { blockade with } \\
\text { labetolol* likely to con- } \\
\text { trol BP surges } \dagger\end{array}$ & $\begin{array}{l}\text { Diastolic BP } \uparrow \text { during } \\
\text { nonselective } \beta \text {-blockade, } \\
\text { but not during selective } \beta \text { - } \\
\text { blockade } \\
\alpha_{1} \text { blockade with } \\
\text { labetolol* may antagon- } \\
\text { ize BP surges } \ddagger+\text { HR } \uparrow\end{array}$ \\
\hline
\end{tabular}

*Tolerance likely within months (Semplicini et al., 1983); $\dagger$ see Nyerberg et al. (1978), ‡rarely BP increases $\uparrow$ (Prichard, 1984). In labetolol responsive acute hypertension due to CNS lesions, e.g. tetanus (Prichard, 1984), the role of adrenaline versus noradrenline remains unclear. $\mathrm{BP}=$ blood pressure; $\mathrm{HR}=$ heart rate.

istics rather than the presence or absence of elevated plasma adrenaline or noradrenaline concentrations. Thus, despite most phaeochromocytoma patients exhibiting higher concentrations of circulating noradrenaline than adrenaline (Bravo et al., 1979), a more important component of the pressor response was attributed to adrenaline. This was because during typical hypertensive surges there are increases in systolic and decreases in diastolic pressure; the latter being converted to variable increases in the presence of nonselective $\beta$-blockade (Prichard \& Ross, 1966). Similarly, five-fold increases in plasma adrenaline (and noradrenaline) have been recorded during exercise (Galbo et al., 1975); and yet isometric exercise results in increased systolic and diastolic pressure (see Table I). The latter observations, as well as the absence of any difference in the extent of systolic or diastolic blood pressure changes during nonselective and selective $\beta$-blockade, indicate that clinically significant amounts of circulating adrenaline are not involved.
Haemodynamic changes with dynamic exercise and other pressor stimuli during beta-blockade

During dynamic exercise systolic pressure and cardiac output increase, probably due to cardiac sympathetic stimulation, increased venous return and arteriolar dilatation in muscles (Jones et al., 1975). Diastolic pressure remains unchanged despite vasodilatation in muscles, indicating vasoconstriction (presumably noradrenergic) occurring elsewhere. As to the impact of $\beta$-blockade on dynamic exercise-induced increments in systolic pressure, there are numerous contradictory reports almost equally divided between those describing no attenuation and those who claim that attenuation occurs. Whilst difficult to reconcile, these apparently conflicting findings (Davidson et al., 1976; Morrison et al., 1982; McLeod et al., 1984) may depend on subtle differences in detail as to the precise format of the exercise (e.g. duration, exhausting or mild, glycogen replete or depleted muscles, treadmill or cycling). Equal confusion surrounds sympathetic involvement in the acute pressor effect of alcohol ingestion, which is confined to heavy drinkers (Potter et al., 1985). Only the systolic blood pressure rises, there is no increment in plasma adrenaline level and only a minimal increase in plasma noradrenaline. Thus, even if neural (noradrenergic) stimulation is entailed, other haemodynamic sequelae of ingesting alcohol appear to prevent the diastolic pressure from rising.

As in normotensives, continuous intra-arterial monitoring of blood pressure showed that hypertensive patients (including one restudied after sotolol treatment), invariably exhibited wildly fluctuating $50-70 \mathrm{~mm}$ elevations in systolic and diastolic blood pressure during coitus (Mann et al., 1982). Another study utilizing automated blood pressure recording, also noted pressor responses during autostimulated sexual arousal in female volunteers (Riley \& Riley, 1981). Pretreatment of the latter with labetolol but not propranolol, was associated with a statistically significant reduction in pressor response.

Cigarette smoking too, may be consistent with predominantly neurogenic (noradrenaline mediated) stimulation; both systolic and diastolic pressures rise, and at least one study (Houben et al., 1981) found no difference in the diastolic pressor increment in patients taking selective or nonselective $\beta$-blockers, despite rises in plasma adrenaline concentration. However, other less clear studies (Freestone \& Ramsay, 1982; Cuspidi et al., 1982; Fogari et al., 1982) reported that after treatment with atenolol, smoking produced lesser surges in diastolic pressure compared to equivalent antihypertensive doses of nonselective $\beta$ blockers.

Similarly, studies showing rises in systolic and diastolic blood pressure in healthy individuals and 
hypertensive patients subjected to brief ( 5 minute) periods of acute mental stress (Heidbreder et al., 1978; Bonelli et al., 1979; Melville \& Raftery, 1981), suggest a mainly neural (noradrenaline mediated) response, despite there being increases in plasma adrenaline (but not noradrenaline) concentrations and heart rate. Consistent with a noradrenergic response, neither selective nor nonselective $\beta$-blockade affected stressprovoked pressor increments. Haemodynamic responses to more prolonged stress appear more complicated, in that both adrenaline and noradrenaline excretion in urine is increased (Lorimer et al., 1971), whilst the surge in systolic pressure is blunted in the presence of propranolol (Dunn et al., 1978).

The features of acute hypoglycaemia (palpitations, tremor, anxiety, hyperventilation) also resemble sympathetic activation. Indeed, in healthy volunteers (Lloyd-Mostyn \& Oram, 1975) and diabetics (Larger et al., 1979) insulin-induced hypoglycaemia produces a haemodynamic effect resembling adrenaline infusion, namely: rises in heart rate and systolic pressure and decreases in diastolic pressure; the diastolic decrements being converted to increments after propranolol (but much less so after metoprolol). After nonselective $\beta$-blockade, the mean change in the diastolic pressure response was small, but a few individuals displayed marked increases after propranolol. To protect the latter, it may be safer to avoid prescribing pure nonselective $\beta$-blockers in 'brittle' diabetics taking hypoglycaemic agents.

\section{Beta-blocker - drug interactions and pressor response}

Intranasally instilled phenylephrine does not usually enter the circulation in amounts sufficient to raise blood pressure even when excessive doses are given in the presence of nasal congestion (Myers \& Iazzetta, 1982). Nevertheless, a small minority of individuals using phenylephrine eye drops (mydriatic) or nose drops (decongestant 'cold cures'), evidently manifest dangerous acute hypertension. A randomized, doubleblind, cross over study in hypertensive patients treated with propranolol and metoprolol (Myers, 1984), revealed that i.v. phenylephrine consistently increased pretreatment diastolic and systolic blood pressure (analogous to noradrenaline) and wide interindividual differences in sensitivity were present. Interestingly, neither $\beta$-blocker enhanced the pressor effect, indicating that $\alpha$-receptor stimulation was not unmasked. Thus, contrary to earlier beliefs, the presence or absence of nonselective $\beta$-blockade seems irrelevant to this issue. Rather, a few patients may be highly sensitive to the pressor action of exogenously administered phenylephrine.

Catecholamines have been used together with infiltrative local anaesthesia in dentistry in order to obtain a bloodless anaesthetic field (reviewed by Cawson $e t$ al., 1983). Noradrenaline (virtually a pure vasoconstrictor), has been largely abandoned for this purpose due to instances of acute hypertensive intracranial bleeding (even fatalities), presumably due to absorption from the site of infiltration or inadvertent i.v. injection. Evidently, the substitution of adrenaline (capable of $\beta$-receptor mediated vasodilatation as well as $\alpha$-receptor mediated vasoconstriction) has made such anaesthesia much safer. Whilst undoubtedly a commendable change, it is not widely appreciated that among those receiving propranolol (or any other nonselective $\beta$-blocker), this practice may nevertheless give rise to unmasked $\alpha$-receptor mediated stimulation and catastrophic hypertension.

Catastrophic hypertension may also follow abrupt withdrawal of clonidine. Such rebound hypertension reviewed by Hansson (1983) and Whitsell (1983), is a complex phenomenon which may be a true blood pressure overshoot, and (akin to phaeochromocytoma) involves increases in circulating adrenaline, noradrenaline and renin as well as enhanced tissue sensitivity. Even without withdrawal of clonidine therapy, the addition of $\beta$-blocker therapy has been implicated in hypertensive reactions (Lilja et al., 1982), and is possibly related to irregular clonidine compliance. The numerous published reports dealing with these issues are very confusing and often difficult to reconcile with each other. It may nevertheless be prudent to regard such rebound hypertension as involving an important contribution due to circulating adrenaline, whilst accepting that life-threatening hypertension may follow clonidine withdrawal irrespective of $\beta$-blockade.

In schizophrenia, similar considerations may apply to the long term use of propranolol in very large doses $(1-3 \mathrm{~g} /$ day) as alternative antipsychotic drugs or adjuncts to phenothiazines (reviewed by Hayes \& Schulz, 1983). Though incompletely documented, such treatment is evidently associated with self limiting, transient systolic and diastolic hypertension and sometimes encephalopathy (Elizur et al., 1979) raising the possibility that large amounts of adrenaline suddenly enter the circulation, and that the presence of propranolol unmasks $\alpha$-receptor mediated vasoconstriction. Whilst it is recognized that schizophrenics are subject to episodes of aggressive behaviour, it is not known whether these are accompanied by release of adrenaline into the circulation. Hence, any explanation to account for hypertensive surges on this basis must be regarded as speculative.

\section{Clinical significance of blood pressure surges}

Large scale clinical surveys and controlled trials have confirmed the unfavourable prognosis of sustained 
hypertension and the benefits of treatment. No equivalent information exists as to the clinical significance of sympathetically provoked transient surges in blood pressure. Nor is it known whether their abolition might be clinically beneficial, in terms of avoiding life threatening events such as subarachnoid haemorrage. The Framingham survey (Kannel, 1975), however, did find an adverse prognosis associated with 'labile hypertension', an entity often associated with sympathetic stimulation and stress. When mild, infrequent and transient, such surges may have no untoward clinical significance, and considering how

\section{References}

BARCROFT, H. \& STARR, I. (1951). Comparison of the actions of adrenaline and noradrenaline on the cardiac output in man. Clinical Science, 10, 295.

BONNELLI, J., HORTNAGL, H., BRUCKE, T.H., MAGOMETSCHNIGG, D., LOCHS, H. \& KAIK, G. (1979). Effect of calculation stress on hemodynamics and plasma catecholamines before and after $\boldsymbol{\beta}$ blockade with propranolol (Inderal) and mepindol sulphate (Corindolan). European Journal of Clinical Pharmacology, 15, 1.

BRAVO, E.L., TARAZI, R.C., RAY, W., GIFFORD, R.W. \& STEWART, B.H. (1979). Circulating and urinary catecholamines in phaeochromocytoma. New England Journal of Medicine, 301, 682.

BROWN, M.J., STRUTHERS, A.D., BURRIN, J.M., DI SILVO, L. \& BROWN, D.C. (1985). The physiological and pharmacological role of presynaptic $\alpha$ - and $\beta$-adrenoceptors in man. British Journal of Clinical Pharmacology, 20, 649.

CAWSON, R.A., CURSON, I. \& WHITTINGTON, D.R. (1983). The hazards of dental local anaesthetics. British Dental Journal, 154, 253.

CUSPIDI, C., ALIRANDI, P.L., CAVALLINI, F. \& SAMPIERI, L. (1982). Effects of short and long term $\beta$ blockade on changes in blood pressure caused by cigarette smoking in normotensive and hypertensive subjects. Drugs, 25 (Suppl 2), 148.

DAVIDSON, C., THADANI, U., SINGLETON, W. \& TAYLOR, S.H. (1976). Comparison of antihypertensive activity of beta blocking drugs during chronic treatment. British Medical Journal, $2,7$.

DUNN, F.G., MELVILLE, D.I., JONES, J.V., LORIMER, A.R. \& LAWRIE, T.D.V. (1978). Standardised stress and hypertension: comparison of effect of propanolol and methyldopa. British Journal of Clinical Pharmacology, 5, 223.

ELIZUR, A., SEGAL, Z., YERET, A., DAVIDSON, S. \& ATSMON, A. (1979). Antipsychotic effect of propranolol on schizophrenics: study of gradual treatment regimen. $P s y$ chopharmacology, 60, 189.

DUNN ET AL. (1978).

ELIZUR, A., SEGAL, Z., YERET, A., DAVIDSON, S. \& ATSMON, A. (1979). Antipsychotic effect of propranolol on schizophrenics: study of gradual treatment regimen. Psychopharacology, 60, 189.

FOGARI, R., PARINI, A. \& FINARDI, G. (1982). Cardiovascular responses to cigarette smoking during adrenergic block in essential hypertension. Drugs, 25 (Suppl 2), 149. universally they have evolved they may actually confer some overall benefit to the body. To avoid converting purely systolic hypertensive surges into systolic and diastolic surges, selective $\beta$-blockade (or $\beta$-plus $\alpha$ blockade) may be preferable to nonselective $\beta$-blockade, whenever adrenaline is liable to enter the circulation in clinically significant amounts. Furthermore, until the precise role of sympathetic stimulation in the pathogenesis of so-called labile hypertension is clarified, indiscriminate treatment of all such patients with nonselective $\beta$-blockers such as propranolol might well be inappropriate.

FREESTONE, S. \& RAMSAY, L.E. (1982). Effect of $\beta$ blockade on the pressor response to coffee plus smoking in patients with mild hypertension. Drugs, 25 (Suppl 2), 141.

GALBO, H., HOLST, J.J. \& CHRISTENSON, N.J. (1975). Glucagon and plasma catecholamine responses to graded and prolonged exercise in man. Journal of Applied Physiology, 38, 70.

GOLDENBERG, M., PINES, K.L., BALDWIN, E. DE B., GREENE, D.C. \& ROH, L.E. (1948). The hemodynamic response of man to norepinephrine and epinephrine and its relation to the problem of hypertension. American Journal of Medicine, 5, 792.

HANSSON, L. (1983). Clinical aspects of blood pressure crisis due to withdrawal of centrally acting antihypertensive drugs. British Journal of Clinical Pharmacology, 15, 485S.

HAYES, P.E. \& SCHULZ, C.S. (1983). The use of $\beta$ adrenergic blocking agents in anxiety disorders and schizophrenia. Pharmacotherapy, 3, 101.

HEIBREDER, E., PAGEL, G., ROCKEL, A. \& HEIDLAND, A. (1978). Beta adrenergic blockade in stress protection: limited effect of metoprolol in psychological stress reaction. European Journal of Clinical Pharmacology, 14, 391.

HOUBEN, H., THIEN, T.H. \& VAN 'T LAAR, A. (1981). Hemodynamic effects of cigarette smoking during chronic selective and non-selective $\beta$ blockade in patients with hypertension. British Journal of Clinical Pharmacology, 12, 67.

JOHNSSON, G. (1975). Influence of metoprolol and propranolol on hemodynamic effects induced by adrenaline and physical work. Acta Pharmacologica et Toxicologica, 36 (Suppl V), 59.

JONES, N.L., CAMPBELL, E.J.M., EDWARDS, R.H.T \& ROBERTSON, D.G. (1975). Cardiovascular adaptation to exercise. In Clinical Exercise Testing, p. 39. Saunders Co.: Philadelphia, London, Toronto.

KANNEL, W.B. (1975). Role of blood pressure in cardiovascular disease: the Framingham study. Angiology, 26, 1.

LARGER, I., BLOHME, G. \& SMITH, U. (1979). Effect of cardioselective and non-cardioselective $\beta$ blockade on the hypoglycemic response in insulin dependent diabetics. Lancet, i, 458.

LILJA, M., JOUNELA, A.J., JUUSTIlA, H. \& PAALZOW, L. (1982). Abrupt and gradual change from clonidine to $\beta$ blockers in hypertension. Acta Medica Scandinavica, 211, 375. 
LLOYD-MOSTYN, R.H. \& ORAM, S. (1975). Modification by propranolol of cardiovascular effects of induced hypoglycemia. Lancet, i, 1213.

LORIMER, A.R., MACFARLANE, P.W., PROVAN, G., DUFFY, T. \& LAWRIE, T.D.V. (1971). Blood pressure and catecholamine responses to 'stress' in normotensive and hypertensive subjects. Cardiovascular Research, 5, 169.

MAN IN 'T'VELD, A.J., BOOMSA, F. \& SCHALEKAMP, M.A.D.H. (1983). Regulation of $\alpha$ and $\beta$ adrenoceptor responsiveness. Studies in patients with chronic autonomic failure. British Journal of Clinical Pharmacology, 15 (Suppl 4), 507S.

MANN, S., MILLAR-CRAIG, M.W., GOULD, B.A., MELVILLE, D.I. \& RAFTERY, E.B. (1982). Coital blood pressure in hypertensives: Cephalgin, syncope, and the effects of betablockade. British Heart Journal, 47, 84.

MCLEOD, A.A., BROWN, J.E., KITCHELL, B.B., SEDOR, F.A., KUHN, D.C., WILlIAMS, R.S. \& SHAND, D.G. (1984). Hemodynamic and metabolic responses to exercise after alpha $_{1}$ beta $_{1}$ and nonselective beta-adrenoceptor blockade in man. American Journal of Medicine, 76, 97.

MELVILLE, E.B. \& RAFTERY, E.B. (1981). Blood pressure changes during acute mental stress in hypertensive subjects, using the Oxford intra arterial system. Journal of Psychosomatic Research, 25, 497.

MORRISON, S.C., KUMANA, C.R., RUDNICK, H.B. \& JONES, N.L. (1982). Selective and nonselective $\beta$-adrenoceptor blockade in hypertension: responses to changes in posture, cold and exercise. Circulation, 65, 1171.

MYERS, M.G. \& IAZZETTA, J.H. (1982). Intranasally administered phenylephrine and blood pressure. Canadian Medical Association Journal, 127, 365.

MYERS, M.G. (1984). Beta adrenoceptor antagonism and pressor response to phenylephrine. Clinical Pharmacology and Therapeutics, 36, 57.
NYBERG, G., VEDIN, A. \& WILHELMSSON, C. (1979). Effects of labetolol and propranolol on blood pressure at rest and during isometric and dynamic exercise. European Journal of Clinical Pharmacology, 16, 299.

POTTER, J.P., MCDONALD, I. \& BEEVERS, G.D. (1985). Proceedings of the Second European Meeting on Hypertension: The acute effects of alcohol on blood pressure and catecholamines in high and low alcohol consuming hypertensives. Ricerca Scientifica ed Educazione Permanente, Suppl 49, Abst 426.

PRICHARD, B.N.C. \& ROSS, E.J. (1966). Use of propranolol in conjunction with alpha receptor blocking drugs in pheochromocytoma. American Journal of Cardiology, 18, 394.

PRICHARD, B.N.C. (1984). Combined $\alpha$ - and $\beta$-receptor inhibition in the treatment of hypertension. Drugs, 28 (Suppl 2), 51.

RILEY, A.J. \& RILEY, E.J. (1981). The effect of labetolol and propranolol on the pressor response to sexual arousal in women. British Journal of Clinical Pharmacology, 12, 341.

SEMPLICINI, A., PESSINA, A.C., ROSSI, G.P., HILDA, M. \& MORANDIN, F. (1983). $\alpha$-adrenoceptor blockade by labetolol during chronic dosing. Clinical Pharmacology and Therapeutics, 33, 278.

VAN HERWAARDEN, C.L.A., BINKHORST, R.A., FENNIS, J.F.M. \& VAN'T LAAR, A. (1977). Effects of adrenaline during treatment with propranolol and metoprolol. British Medical Journal, 1, 1029.

VAN HERWAARDEN, C.L.A., BINKHORST, R.A., FENNIS, J.F.M. \& VAN'T LAAR, A. (1979). Effects of propranolol and metoprolol on haemodynamic and respiratory indices and on perceived exertion during exercise in hypertensive patients. British Heart Journal, 41, 99.

WHITSELL, T. (1983). Abrupt cessation of centrally acting antihypertensive agents. Chest, 83,400 . 